\title{
Inhibition of Soil Methane Oxidation by Fertilizer Application: an Intriguing but Persistent Paradigm
}

\author{
Virendra Kumar Mishra ${ }^{1,2^{*}}$, Reetika Shukla ${ }^{1}$, Prabhu Nath Shukla ${ }^{3}$ \\ ${ }^{1}$ Department of Environmental Science, Indira Gandhi National Tribal University, Amarkantak, MP, India, \\ 486887 \\ ${ }^{2}$ Institute of Environment and sustainable Development, Banaras Hindu University, Varanasi, India \\ ${ }^{3}$ Deputy Conservator of Forest, Department of Forest, Kolhapur, Maharashtra, India \\ ${ }^{*}$ Email: virendra78@gmail.com
}

\begin{abstract}
Methane $\left(\mathrm{CH}_{4}\right)$ is one of the most important greenhouse gases and is oxidized by the methanotrophic bacteria in the soil. Present work is an effort to review the available information in this regard and present them in a systematic way. In this review, we concluded that low $\mathrm{NH}_{4}^{+}$ concentration can be supportive to the methane oxidation and growth of the methanotrophs. However, their high contents suppress the methanotrophic bacteria by inhibiting the enzymes particularly methane monooxygenase (MMO) involved in the methane oxidation. There are a range of the soil and environmental factors such as type of soil and vegetation, methane availability, amount and exposure time of ammonium, and type of methanotrophic community dominating in an ecosystem, which affect the response of the methanotrophic bacteria towards the fertilizer application. However, still there are several gaps in our knowledge as complex interaction of edhapic factors affecting the availability of ammonium is unraveled.
\end{abstract}

Key Words: Methane, soil methane oxidation, fertilizer application, ammonium fertilizer, nitrate fertilizer, organic fertilizer

\section{Introduction}

Methane $\left(\mathrm{CH}_{4}\right)$ is a radiatively active hydrocarbon present in the atmosphere. Its global warming potential is 21 , which makes it responsible for approximately $15 \%$ of the total greenhouse effects [1], [2], [3]. The estimates of annual methane emission were around $300 \mathrm{Tg}$ during 2000 which was projected to increase up to 400 to $600 \mathrm{Tg}$ in 2010 [4]. Global methane emission is balanced by the atmospheric and soil methane sink activity. Atmospheric sink activity is responsible for the $90 \%$ of the global methane sink capacity, while rest $10 \%$ is mediated by methane oxidation capacity of the soil. Soil methane oxidation is carried out by the aerobic eubacteria called methanotrophic bacteria (MB) or methane oxidizing bacteria (MOB). Growth of methanotrophs is limited to $\mathrm{CH}_{4}$, though some may utilize methanol and in some other cases formate, formaldehyde, methylamine etc. [5]. Methanotrophs oxidize methane in the presence of the enzyme methane monooxygenase (MMO). They are divided into Type I, Type II, and Type $\mathrm{X}$ based on their intra membrane pattern, physiological characteristics, chemotaxonomic nature and phylogenetic position [6]. However, recently it has been suggested that they should be categorized into only Type I and Type II. Type I methanotrophs ( $\alpha$-proteobacteria) include Methylomonas, Methylobacter, Methylosarcina, Methylomicrobium, Methylococcus, and Methylocaldum, while Type II methanotrophs ( $\gamma$-Proteobacteria) include Methylosinus, Methylocystis, Methylocella and Methylocapsa. A range of natural as well as anthropogenic factors influence the methane oxidation potential of the soil. Among them, effect of the fertilizer application on the methane oxidation remains one of the most studied aspects. Nitrogenous fertilizers are generally thought to have an important role in regulating methane oxidation. In this context, the effect of ammonium on methane oxidation activity in different soil types is an important aspect and has been instigated by several works. The inhibition of methane consumption potential of soils by mineral fertilizer was firstly reported in temperate forest soil [7]. Since then, a range of ecosystems have been studied to assess the consequences of fertilizer application which have given contradictory reports depending upon the nature and amount of fertilizer, longevity of the treatment, type of ecosystem, and edhapic factors prevailing in a particular ecosystem 
[8]. There are several reports suggesting the inhibition of the methane oxidation capacity of the soil by the application of the mineral fertilizers. The subject is of high relevance, yet no systematic review is available in this context. The present work is an effort to review the available information in this regard and present them in a systematic way. It is noteworthy that the interactions between the nitrogen and methane cycle are complex and not completely understood. Several studies were performed to investigate the effects of $\mathrm{N}$ fertilizers on methane oxidation to better understand the interactions between the methanotrophic community and ammonia oxidizing bacteria. Under this review we tried to develop a complete picture of this process which is delicately balanced by nature. The accounts of methane consumption potential of the soil as affected by the different fertilizers (Table 1) and possible operative mechanisms have been discussed in coming sections.

\section{$2 \quad$ Ammonium Fertilizers}

Out of the total fertilizer consumption, share of nitrogenous fertilizers is $80-90 \%$ of which ammonium fertilizers account for 70\% [9]. Ammonium application has shown conflicting results in relation to inhibition of soil methane oxidation [10], [11] stimulation [12] or even no effect [13], [14] of $\mathrm{CH}_{4}$ oxidation, consumption or sink activity which may vary from upland (e.g., forest and grassland) to lowland soils (e.g., rice paddies and fresh water marshes) [15],[16], Longevity of $\mathrm{NH}_{4}^{+}$application also affected the response of methanotrophic bacteria. In short term, $\mathrm{NH}_{4}^{+}$was either inhibitory [17] or exerted no effect [18] while in long term, it usually showed inhibitory effect. [18], [17] The inhibition of $\mathrm{NH}_{4}{ }^{+}$still occured even when $\mathrm{NH}_{4}{ }^{+}$concentration has decreased to the background levels [19], [20], [21]. Some scientists have observed that inhibitory effect decreased after long term $\mathrm{NH}_{4}^{+}$application [17],[22],[23]. It might be due to increased formation of organic $\mathrm{C}$ by $\mathrm{N}$ application resulting into the immobilization of excess $\mathrm{NH}_{4}^{+}-\mathrm{N}$. Similarly, inhibitory effect was found to disappear after yearly application of fertilizer [24] probably, due to adaptation in methanotrophic population against the elevated ammonium concentration in long term. Longevity of inhibition was also dependent upon the endogenous level of the $\mathrm{NH}_{4}^{+}$in soils as $\mathrm{CH}_{4}$ uptake activity of the forest soils characterized by $\mathrm{N}$ limitation recovered rapidly from the inhibitory effect [25]. Level of the ammonium added may also play a critical role in determining the response of the soil. At low $\mathrm{NH}_{4}{ }^{+}$concentration, $\mathrm{CH}_{4}$ oxidation activity was unaffected, while at higher concentration $\mathrm{CH}_{4}$ oxidation was significantly reduced. Any factor ensuring the persistent but slow release of the $\mathrm{N}$ usually enhanced methane uptake. Mori et al. observed that nitrogen fixed by leguminous plants did not reduce the $\mathrm{CH}_{4}$ uptake probably due to long term sustained and slow release of $\mathrm{NH}_{4}^{+}$in soil [26].

\section{$3 \quad$ Factors Affecting Soil Methane Oxidation}

A range of the edaphic and natural factors affect the level of reactive and available $\mathrm{NH}_{4}^{+}$in a particular ecosystem. The effect of ammonium is controlled by $\mathrm{CH}_{4}$ concentration in the environment. In nonwater saturated soils, where $\mathrm{CH}_{4}$ uptake took place at low $\mathrm{CH}_{4}$ concentrations, increased $\mathrm{NH}_{4}^{+}$ availability usually suppressed $\mathrm{CH}_{4}$ oxidation rate [7],[27],[28],[29],[30]. While, in water saturated wetland soils characterized by high $\mathrm{CH}_{4}$ concentration, the effect was contradictory, with reports ranging from inhibition to stimulation [31],[32],[33],[34],[35]. The initial inhibitory effect of $\mathrm{NH}_{4}^{+}$was eliminated during subsequent incubations under high $\mathrm{CH}_{4}$ concentration $(>1000 \mathrm{ppm}$ ), while the effect was persistent at low methane concentration $(<500 \mathrm{ppm})$ [35]. In its agreement, it has been reported that $\mathrm{N}$ fertilization suppressed $\mathrm{CH}_{4}$ oxidation in surface soil, while having no effect in subsurface soil [36],[37]. Higher methane concentration through endogenous methane production in subsurface layer may be responsible for no effect of fertilizer on methane oxidation in subsurface soil.

Besides, soil types have also been reported to significantly affect the relation between ammonium and $\mathrm{CH}_{4}$ oxidation rate. Clay soil binds positively charged $\mathrm{NH}_{4}{ }^{+}$strongly, thus preventing its leaching and ensuring long term availability, while at the same time in sandy soil it would be readily available to negatively affect the methane oxidation. Tanthachoom et al. noticed that the effect of $\mathrm{NH}_{4}^{+} \mathrm{was}$ inhibitory in sandy loam soil, while at the same time, stimulatory to some extent in compost soil which is characterized by low $\mathrm{pH}$ and high humus content. In soil, rich in organic $\mathrm{C}$, excess ammonium is immobilized, thus releasing the $\mathrm{NH}_{4}{ }^{+}$slowly but persistently affecting the methane oxidation favorably 
[38]. At the same time, increased soil organic C is usually accompanied with increased porosity, increasing the gas diffusion, thus complementing the positive effect of $\mathrm{NH}_{4}{ }^{+}$. In soil with high humus content, excess $\mathrm{NH}_{4}^{+}$ameliorates the low $\mathrm{pH}$ to some extent also making the soil supportive for the methanotrophic growths which usually have been reported to be optimally near neutral pH (ca. 6) in most of the cases, Hanson $\&$ Hanson and Chen-Rui et al. suggested that it might happen due to improvement in $\mathrm{C} / \mathrm{N}$ ratio of the investigated soil [6], [39].

Similarly, soil pH may also be crucial determinant for the response of $\mathrm{NH}_{4}^{+}$. At lower $\mathrm{pH}$ most of the added ammonium will be in the form of $\mathrm{NH}_{4}{ }^{+}$while in alkaline soil a significant proportion will escape in the form of ammonia, so the response will be different from the expectation [40]. Unfortunately, no study has been conducted to fill these gaps in knowledge considering the extent of acidic soil world wide and increasing the extent and amount of atmospheric acid deposition. Effect of ammonium was also connected with type of forest soil. Rigler and Zechmeister-Boltenstern reported that $\mathrm{NH}_{4}^{+}$addition retarded $\mathrm{CH}_{4}$ oxidation in deciduous forest soil, but accelerated it in the coniferous forest soil. Reason may be that coniferous forest soils have low $\mathrm{pH}$, high $\mathrm{C} / \mathrm{N}$ ratio; so, $\mathrm{NH}_{4}$ application ameliorated the hostile condition by reversing these adverse edaphic factors [15]. The chemical nature of the ammonium salt also affected the availability of ammonium [41]. Different anions were having varying effect on desorption of ammonium. It was evidenced by the observations of King and Schnell, who reported that $\mathrm{NH}_{4} \mathrm{Cl}$ caused greater inhibition compared to $\mathrm{NH}_{4}\left(\mathrm{SO}_{4}\right)_{2}$ presumably due to increased ammonium desorption by the sulphate. [41]Likewise, the load of the non ammonical salts may also influence the desorption potential of the ammonium methane oxidation differently.[41] Non ammonical salts were found as essential controls for partitioning ammonium inhibition between the nonspecific and MMO related mechanisms [42], [43].

\section{Mechanisms for the Inhibition of Methane Oxidation by Ammonium Fertilizers}

Based on findings of different studies an explanatory hypothesis has been proposed (Fig. 1) to explain the mechanism of inhibition of methane oxidation by ammonium fertilizers. Among them, the most widely held theory is that MMO enzymes is able to oxidize $\mathrm{NH}_{4}^{+}$to $\mathrm{NO}_{2}^{-}$also, along with oxidizing methane to methanol [44], [45], [46], [47] and therefore $\mathrm{NH}_{4}{ }^{+}$acts as a competitive inhibitor of MMO [48], [45]. Whereas, Dunfiled and Knowles, could not detect whether this competition is simple or partial [36]. However, according to them simple competition inhibition is more likely. It is due to high level of similarity between pMMO (particulate methane monooxygenase) found in methanotrophs and AMO (ammonia monooxygenase) enzyme found in ammonium oxidizing bacteria [49]. These similarities include a high degree of amino acid sequence identity, similar protein complex structures, similar substrate and broadly inhibition profiles [50], [51], [52]. Methanotrophs are unable to obtain energy from the oxidation of ammonium [45]. Direct evidence for nitrification by methanotrophs shows in [48]. Yoshinari et al, has been given only for pure cultures. In most of the natural ecosystems, it has been demonstrated only indirectly by means of the inhibitor-sensitive ${ }^{14} \mathrm{CH}_{4} /{ }^{14} \mathrm{CO}$ oxidation ratio, which is higher for methanotrophs than for nitrifiers [53], [54]. Several inhibitors (e.g., $\mathrm{C}_{2} \mathrm{H}_{2}, \mathrm{CH}_{3} \mathrm{~F}$, dimethylether, allylsulfide, allylthiourea, dicyandiamide, picolinic acid, and difluoromethane) have been evaluated for their potential to selectively knock out one group of bacteria without affecting the other [55]. However, only allyl sulfide [56] and picolinic acid [57] showed potential for discrimination, although neither was able to discriminate 100\%. O'Neill and Wilikinson [48], suggested that nitrite inhibits the formate dehydrogenase, an enzyme producing reductant for $\mathrm{CH}_{4}$ oxidation. The hydroxylamine $\left(\mathrm{NH}_{2} \mathrm{OH}\right)$ and nitrite $\left(\mathrm{NO}_{2}^{-}\right)$produced by $\mathrm{NH}_{4}^{+}$oxidation was also suggested to suppress methanotrophic activity [29], [58]. There are reports indicating that $\mathrm{NH}_{4}^{+}$as well as high concentration of $\mathrm{NH}_{3}$ inhibits another key enzyme of methane cycle, methanol dehydrogenase (MDH) converting methanol to formaldehyde. In its agreement, Boiesen and Arvin reported that ammonia is a weak competitive inhibitor as observed by other researchers and relatively high levels ammonia $(70 \mathrm{mg} / \mathrm{l})$ was able to inhibit the methane consumption [59]. Addition of $\mathrm{NH}_{4}^{+}$fertilizers may also stimulate the ammonium oxidizing bacteria (AMO) which may occupy niche of certain methanotrophic bacteria resulting into reduced $\mathrm{CH}_{4}$ oxidation [60], [61],[62]. However, their population size is not significantly higher than MOB in soil [63] and the rate of $\mathrm{CH}_{4}$ oxidation carried out by them is about 100-10,000 times less than methanotrophs 
[64]. Henckel et al., [65] could not detect this group of bacteria in the surface forest soil through amplification of the amoA gene of ammonium oxidizers. So probably they are not the candidates responsible for atmospheric methane uptake in soil [66]. Similarly, several other studies including those of the Bodelier and Frenzel conducted in rice field andHenckel et al. in forest soil revealed insignificant contribution of nitrifying population in methane oxidation [55], [65]. ${ }^{14} \mathrm{C}$ PLFA analysis also excluded any significant role of ammonium oxidizers in the metabolism of atmospheric $\mathrm{CH}_{4}$ [67]. Positive relation between ammonium and methane oxidation at higher methane concentration is resulted from the inability of ammonium to competitively inhibit the MMO, while at same time supplying requisite level of nutritional N. Another explanation may be that nitrifying bacteria are stimulated under high ammonium concentration, which in turn oxidizes $\mathrm{CH}_{4}$ under elevated $\mathrm{CH}_{4}$ concentration [62], [68]. Work of Dunfield and Knowles [36] suggests that instead of $\mathrm{NH}_{4}^{+}, \mathrm{NO}_{2}^{-2}$ is more responsible for the inhibition of the methane uptake and production of the $\mathrm{NO}_{2}^{-2}$ from the $\mathrm{NH}_{4}{ }^{+}$is diminished under high methane concentration. However, few studies have reported the inhibition of methane oxidation or stimulation of the $\mathrm{NH}_{4}$ oxidation even at higher methane concentration[29] [46]. It is presumably due to alleviation of NADH limitation [36]. Another study by Gulledge and Schimel concluded that the increased inhibition of $\mathrm{CH}_{4}$ oxidation by mineral $\mathrm{N}$ under higher methane as observed by King and Schnell was due to $\mathrm{Cl}^{-}$, the counter-ion of $\mathrm{NH}_{4}^{+}$in their study [29], [69]. Whalen and Reeburgh also expressed same view [37]. However, crucial role of $\mathrm{Cl}^{-}$as suggested by these workers was contradicted by King and Schnell, who reported that $\left(\mathrm{NH}_{4}\right)_{2} \mathrm{SO}_{4}$ also inhibited the methane oxidation under high methane concentration [41].

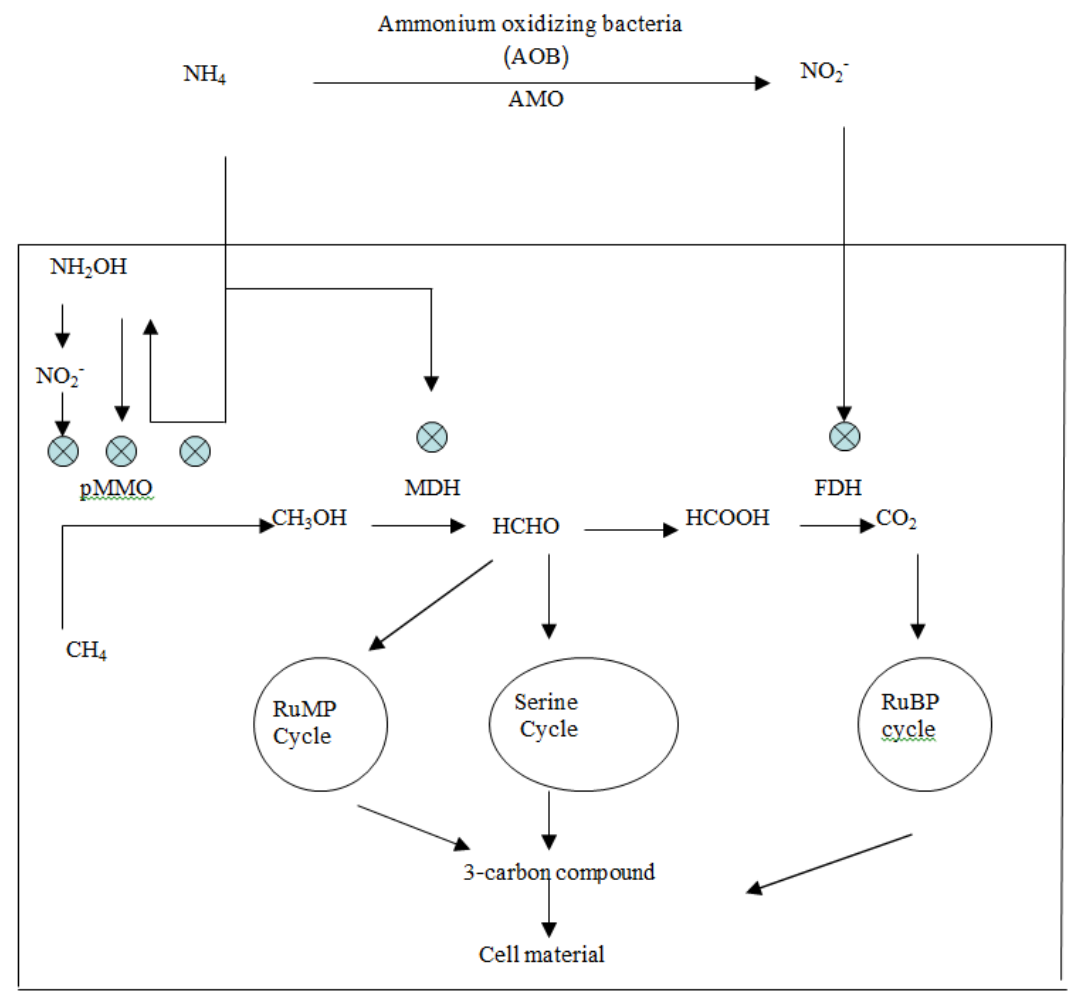

Figure 1. Enzymatic inhibition of the methanotrophic bacteria by the ammonium and derived products

Besides, $\mathrm{NH}_{4}^{+}$can have non-specific inhibition mechanisms which may include an inhibitory salt effect (osmotic stress) and decrease in soil pH [69], [41], [36]. Former, assumption has been proposed due to the inhibition brought about by several other nitrogenous and non-nitrogenous salts also [70], [41], [69], [71]. It was also ensured by the conductivity measurement of the soil after salt addition [72]. Saari et al., [72] observed that methane oxidising microbes were more sensitive to the salt treatment than other soil microbes based on the $\mathrm{CO}_{2}$ production rates. Further, they suggested that $\mathrm{pH}$ variation following the ammonium amendments have very little effect if any, contrary to the earlier reports. In addition to the 
above mechanisms, nitrogen addition may increase root biomass in forest soil resulting into decreased soil porosity and restricted gas diffusion hindering the $\mathrm{CH}_{4}$ oxidation [73]. Steudler et al. [74] suggested that the direct impact of ammonium is related to its inhibitory effect on the $\mathrm{CH}_{4}$ oxidizing bacteria, while its indirect effect is causedmby change in nitrogen turnover rates. Other studies also suggested that the $\mathrm{N}$ turnover rate rather than the mineral $\mathrm{N}$ content influences the $\mathrm{CH}_{4}$ oxidation. [19] Evidently, low nitrogen turnover is responsible for high $\mathrm{CH}_{4}$ oxidation rate in forest soil [75],[64],[76].

Net effect of the ammonium on the methane sink activity of the soil (Fig. 2) should be dependent on the response of both the methanotrophs as well as methanogenss to fertilizer additions. However, related studies have been seldom carried out in any ecosystem. Some idea can be generated by the work of Zhang et al. in the soils of submerged wetland [12]. They have suggested three effects of ammonium application on methanogens stimulating plant growth and therefore intensifying $\mathrm{CH}_{4}$ emission by providing more methanogenic substrates or improving aerenchyma conditions, and intensifying $\mathrm{CH}_{4}$ oxidation by providing $\mathrm{O}_{2}$ to the rhizosphere due to improvement of aerenchyma conduits and accordingly decreasing $\mathrm{CH}_{4}$ emission.

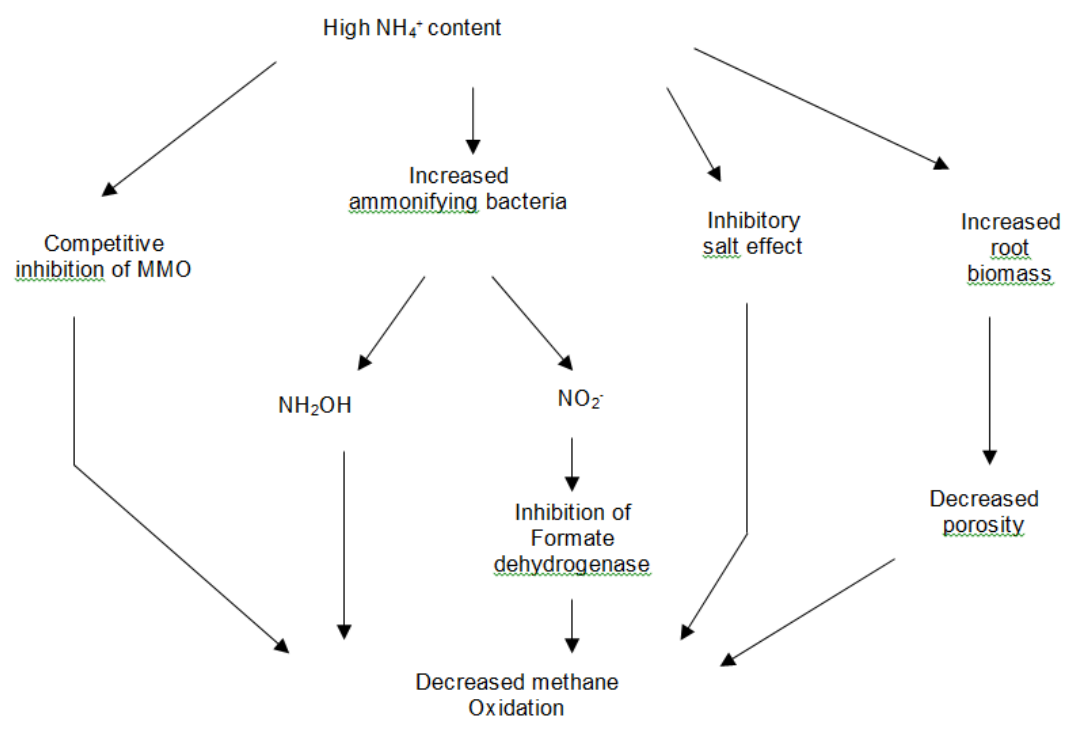

Figure 2. Proposed mechanisms for inhibition of the methane consumption

Net effect of the ammonium on the methane sink activity of the soil should be dependent on the response of both the methanotrophs as well as methanogenss to fertilizer additions.

\section{$5 \quad$ Ammonium Fertilizers and Methanotrophic Community}

Ammonium exerts its effect at the community level also. Enumeration of methanotrophic population size through MPN (most probable number) technique showed that ammonium application decreased the methanotrophic population size [77],[10]. Molecular and biochemical techniques have also yielded similar results. Seghers et al, observed that fatty acids characteristics for methanotrophs were less abundant in the soil treated with mineral fertilizer compared to that treated with compost [78]. It has been suggested that differential responses of soil subsequent to fertilizer application may be due to different dominating methanotrophic communities in the soil [60], [79], [80]. PLFA (phospholipid fatty acid analysis) along with SIP (stable isotope probing) revealed that application of $\mathrm{NH}_{4}^{+}$in presence of high $\mathrm{CH}_{4}$ concentration reduced the amount of ${ }^{13} \mathrm{C}$ incorporated into majority of PLFA except few, indicating that suppression of one group of methanotrophs occurred more readily than others [81]. Type I methanotrophs are stimulated under the presence of elevated $\mathrm{NH}_{4}{ }^{+}$concentration contrary to Type II, possibly due to $\mathrm{N}_{2}$ fixing ability of latter [34],[80],[82],[83],[84]. Lau et al., [84] performed rRNA targeted quantitative hybridization in the pine forest soil and suggested that Type II were more sensitive to nitrogen addition. However, all the Type II methanotrophs are not prone to the $\mathrm{NH}_{4}^{+}$addition [84]. Noll 
et al., [85] observed that exogenous $\mathrm{NH}_{4}^{+}$application in rice field soil activated only a small subset belonging to Methylobacterium/Methylocaldum within Type II methanotrophs. Both low as well as high affinity methanotrophs are adversely affected by the $\mathrm{NH}_{4}{ }^{+}$treatment [86].

\section{$6 \quad$ Effect of Nitrite}

Applications of $\mathrm{NO}_{2}^{-2}$ resulted into inhibition of methane oxidation soils and sediments incubated in laboratory conditions found that exogenous $\mathrm{NO}_{2}^{-2}$ was a more effective inhibitor of $\mathrm{CH}_{4}$ consumption than $\mathrm{NH}_{4}{ }^{+}$in an acid forest soil (59\% and $42 \%$ inhibition, respectively) [29],[87]. In forest soil, the inhibitory effect of $\mathrm{NO}_{2}^{-2}$ was shown to be greater and more enduring than the direct effect of $\mathrm{NH}_{4}{ }^{+}$. Dunfield and Knowles [36] observed that addition of $\mathrm{NO}_{2}^{-2}\left(40 \mathrm{mg} \mathrm{N} \mathrm{kg}{ }^{-1}\right.$ soil) inhibited $\mathrm{CH}_{4}$ oxidation by $84 \%$ initially, which decreased upto $41 \%$ after $48 \mathrm{~h}$ but its negative effect persisted till it was completely converted into $\mathrm{NO}_{3}$. Same workers reported nitrite has minimal secondary toxic effects relative to direct inhibition caused by ammonium. The relative inhibition caused by $\mathrm{NO}_{2}^{-2}$ was highest at low $\mathrm{CH}_{4}$ concentrations however, its production through nitrification by methanotrophic culture increased with methane concentration [29],[36]. Nitrite is a non-competitive inhibitor of methane oxidation. It can inhibit formate dehydrogenase and can contribute to NADH limitation, explaining its greater influence on $\mathrm{CH}_{4}$ limited cells [29],[36],[88]. A high metabolic rate might also be necessary to export toxic, cellular $\mathrm{NO}_{2}^{-2}$ produced by the nitrification in methanotrophs [36]. It was found that $\mathrm{NO}_{2}^{-2}$ concentrations produced through nitrification of the ammonium were lower than required for inhibition of methane oxidation, but its intracellular concentration may be higher than required, due to which methanotrophs might produce $\mathrm{NO}_{2}^{-2}$ themselves [36]. Production of $\mathrm{NO}_{2}$ from $\mathrm{NH}_{4}{ }^{+}$in methanotrophs cultures increased with increasing $\mathrm{CH}_{4}$ concentrations [87] further implicate $\mathrm{NO}_{2}^{-2}$ as a significant inhibitor, as previously noted [29],[36],[89].

Perhaps the absolute concentration and time of exposure affect the ability of methanotrophs to recover from $\mathrm{NO}_{2}^{-2}$ inhibition and perhaps the extremely high natural nitrification rate of this humisol shields methanotrophs from $\mathrm{NO}_{2}$ [36]. Hutsch suggested that in soils with optimal conditions for nitrification, the inhibitory effect of $\mathrm{NH}_{4}^{+}$via $\mathrm{NO}_{2}^{-2}$ is unlikely as it is immediately oxidized as soon as it is produced. Therefore, the observed $64 \%$ inhibition of $\mathrm{CH}_{4}$ oxidation after nitrification of the added $\mathrm{N}$ could have partly resulted from the concurrent drop in soil $\mathrm{pH}[90]$.

\section{$7 \quad$ Effects of Nitrate Fertilizers}

Similar to the ammonium, there are conflicting results about the influence of nitrate addition on the methane oxidation activity of the soil. Several workers have reported that there was no effect of nitrate $\left(\mathrm{NO}_{3}{ }^{-}\right)$on methane oxidation [28], [29], and [38], while other workers have suggested that its effect was dose dependent. Lower concentration of nitrate has neither effect on methane consumption such as in deciduous forest soil, nor stimulatory effect such as in spruce forest soil; however, at higher concentrations, it suppressed the methane consumption at both sites [15]. In case of inhibition caused by the nitrate, the extent and duration was usually less compared to ammonium [29],[88],[92],[93]. However, an effect more acute than was caused by ammonium common. After nitrate addition, 10 to $86 \%$ reduction in the $\mathrm{CH}_{4}$ oxidation rate was observed in forest soils [3]. Studies on pure cultures of $\mathrm{CH}_{4}$ oxidizers have also suggested a direct inhibitory effect of nitrate on methanotrophs [3]. It may be due to toxic effect of $\mathrm{NO}_{3}^{-}$itself or $\mathrm{NO}_{2}^{-}$produced via $\mathrm{NO}_{3}^{-}$reduction. However, the exact mechanism for this inhibition is still unknown. Wang and Ineson suggested that cations associated with nitrate rather than nitrate itself are responsible for producing the inhibitory effect. Like ammonium, nitrate also affects both low and high affinity methanotrophs [46]. However, effect was direct on low affinity methanotrophs but indirect on high affinity methanotrophs [86],[93].

\section{Effects of Organic Fertilizers}

Organic fertilizer treatments have either no effect on $\mathrm{CH}_{4}$ oxidation rate or inductive effect [18], [94]. But effect was negative when added in combination with mineral fertilizer, this may be due to immobilization of added mineral $\mathrm{N}$ and their regular release thereafter [94]. Both low and high affinity 
methanotrophs are stimulated by the application of the organic fertilizer [86]. Organic fertilizer induced some particular group of methanotrophs different from those induced by mineral fertilizer. It was evidenced by DGGE (denaturing gradient gel electrophoresis) analysis of $16 \mathrm{~s}$ rRNA gene fragment specific for methanotrophs which revealed a distinct community between mineral and organic fertilized soils as extra Type I methanotrophic bands became visible in the organic fertilized soils [95],[96 ].

\section{$9 \quad$ Global Implications and Future Perspective}

Methane source capacity of the soil is dependent upon the methane consumption potential of the soil which is ultimately dependent upon the several natural and anthropogenic factors prevailing in a particular ecosystem. The matter has become more complex by the effect inflicted by the fertilizer on methane consumption [97],[98],[99],[100]. The accounts of methane consumption potential of the soil as affected by the different fertilizers are given in table 1 and under this we try to discuss various operative mechanisms. Application of the fertilizer has increased to elevate crop production and feed the everincreasing human population particularly since green revolution started in Asian countries during 1950s. Further, for several years developed countries have resorted to fertilizing the natural forest usually characterized by the $\mathrm{N}$ limitation, with the aim of increasing forest productivity (Fig.3). World wide consumption of nitrogenous fertilizer increased from $13 \mathrm{mt}$ (million tones) in 1962 to $97 \mathrm{mt}$ in 2006 , which is projected to reach up to $118 \mathrm{mt}$ in 2011, [9]. This increase is likely to be caused by the high domestic demand in the Asian countries which was responsible for $62 \%$ of the total global fertilizer consumption [9]. Besides, these regions harbor vast rice fields (90\% of the total world) and large cattle population. The cumulative effect of both the factors is likely to affect the share of these countries in global green house gas emission. Due to obligations set under the Kyoto protocol to the different countries for reducing the emission of green house gas it is important to precisely determine the methane source capacity of different regions on the globe. It will require the effect of the nitrogenous fertilizers on the methane oxidation activity.
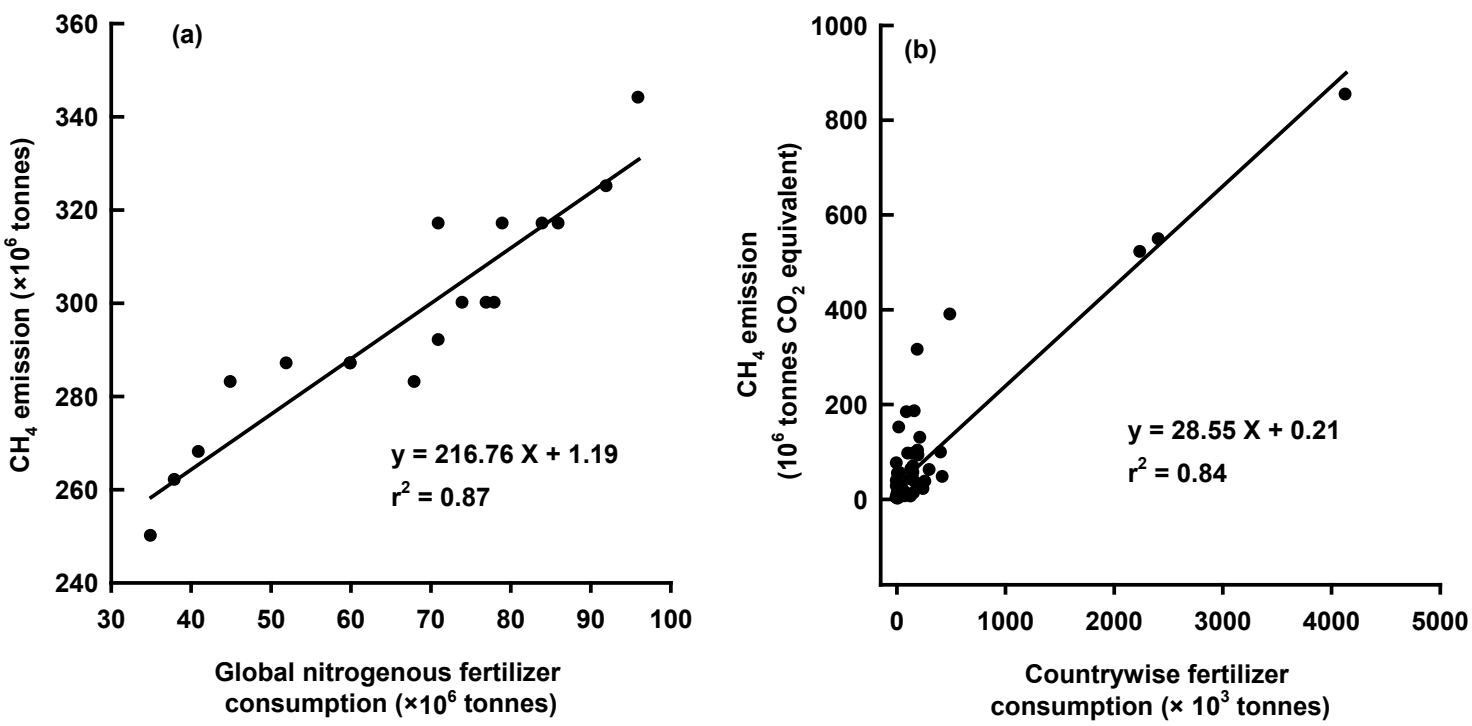

Figure 3. Regression analysis between (a) yearly global fertilizer consumption and methane emission and (b) country wise fertilizer consumption and methane emission

From the above discussion, it is clear that response of methane oxidation and methanotrophic bacteria towards the nitrogenous fertilizers depends upon several factors such as soil type, type of vegetation, methane availability, amount and exposure time of ammonium and type of methanotrophic 
community dominating in a ecosystem. However, the story is still not complete and there are many gaps in knowledge regarding the response of this bacterial group to fertilizer amendments. The complex interactions between the various natural and anthropogenic factors that affect the availability of ammonium for the MOB population have to be explored. Further, community level investigation has not been carried out to find out the response of high affinity methanotrophic community; whether the community size shrink or shift in response to elevated $\mathrm{NH}_{4}{ }^{+}$concentration is not fully understood. Since inhibition of methane oxidation will increase the atmospheric methane load and increased green house affect, we can safely recommend that instead of conventional fertilizers we should use slow release fertilizer in agroecosystems. We should again resort to organic fertilizers which will alleviate the negative effect of the mineral fertilizer as well as decrease the methane emission from the stored organic manures by creating aerobic condition.

Table 1. Inhibitory effects of inorganic nitrogen on methane oxidation in various forest soils

\begin{tabular}{|c|c|c|c|c|}
\hline Study site & Nitrogen (concentration) & $\begin{array}{l}\mathrm{CH}_{4} \\
\text { concentration } \\
\end{array}$ & Effect & References \\
\hline Pure culture & $\mathrm{NH}_{4} \mathrm{Cl}(>0.05 \%(\mathrm{w} / \mathrm{v}))$ & $>1$ to $10 \mathrm{mM}$ & $5 \%$ reduction & [97] \\
\hline Taiga forest & 200 Kg Nha $^{-1} \mathrm{y}^{-1}$ & Ambient air & No effect & [98] \\
\hline $\begin{array}{l}\text { Canada } \\
\text { coniferous } \\
\text { forest } \\
\end{array}$ & $\begin{array}{l}\left(\mathrm{NH}_{4}\right)_{2} \mathrm{SO}_{4}(5 \text { and } 10 \mathrm{mM}) \\
\mathrm{NH}_{4} \mathrm{Cl}(10 \mathrm{mM}) \\
\mathrm{NaNO}_{3}(10 \mathrm{mM})\end{array}$ & $10 \mathrm{ppm}$ & $\begin{array}{l}61-95 \% \text { reduction } \\
93 \% \text { reduction } \\
75 \% \text { reduction } \\
\end{array}$ & {$[75]$} \\
\hline $\begin{array}{l}\text { Pure culture of } \\
\text { methanotroph }\end{array}$ & $\begin{array}{l}\mathrm{NH}_{4} \mathrm{Cl}(0-200 \mu \mathrm{M}) \\
\mathrm{NH}_{4} \mathrm{Cl}(500 \mu \mathrm{M}) \\
\end{array}$ & $\begin{array}{l}100 \mathrm{ppm} \\
1.7 \text { to } 1000 \mathrm{ppm} \\
\end{array}$ & $\begin{array}{l}20-75 \% \\
40-100 \% \\
\end{array}$ & {$[29]$} \\
\hline $\begin{array}{l}\text { Scot pine } \\
\text { forest, Norway }\end{array}$ & $\mathrm{NH}_{4} \mathrm{NO}_{3}\left(30\right.$ and $\left.90 \mathrm{Kg} \mathrm{hm} \mathrm{h}^{-2} \mathrm{a}^{-}\right)$ & Ambient air & $\begin{array}{l}85 \text { and } 62 \% \\
\text { reduction }\end{array}$ & {$[86]$} \\
\hline $\begin{array}{l}\text { Scotland } \\
\text { deciduous forest }\end{array}$ & $\mathrm{NH}_{4} \mathrm{NO}_{3}\left(150\right.$ or $\left.226 \mathrm{~kg} \mathrm{~N} \mathrm{ha}{ }^{-1}\right)$ & Ambient air & reduction & {$[11]$} \\
\hline $\begin{array}{l}\text { Taiga forest, } \\
\text { USA }\end{array}$ & $\mathrm{NH}_{4} \mathrm{NO}_{3}\left(60\right.$ and $\left.50 \mathrm{~kg} \mathrm{~N} \mathrm{ha}^{-1} \mathrm{y}^{-1}\right)$ & Ambient air & $0-75 \%$ reduction & {$[60]$} \\
\hline $\begin{array}{l}\text { Scotland } \\
\text { coniferous } \\
\text { forest }\end{array}$ & $\mathrm{NH}_{4} \mathrm{NO}_{3}, \mathrm{NaNO}_{3}, \mathrm{NH}_{4} \mathrm{Cl}: 40 \mathrm{~kg} \mathrm{~N} \mathrm{ha}^{-1}$ & Ambient air & $\begin{array}{l}\mathrm{NH}_{4} \mathrm{NO}_{3}: 87 \% \\
\mathrm{NaNO}_{3}: 86 \% \\
\mathrm{NH}_{4} \mathrm{Cl}: 70 \% \\
\mathrm{NaCl}: 75 \%\end{array}$ & {$[92]$} \\
\hline $\begin{array}{l}\text { Maine forest } \\
\text { soil, Germany }\end{array}$ & $\begin{array}{l}\mathrm{NH}_{4} \mathrm{Cl}\left(1 \mathrm{mM} \mathrm{g} \mathrm{soil}{ }^{-1}\right) \\
\left(\mathrm{NH}_{4}\right)_{2} \mathrm{SO}_{4}\left(1 \mathrm{mM} \mathrm{g} \mathrm{soil}{ }^{-1}\right)\end{array}$ & $\begin{array}{l}1.7 \mathrm{ppm} \\
270 \mathrm{ppm} \\
1.7 \mathrm{ppm} \\
270 \mathrm{ppm} \\
\end{array}$ & $\begin{array}{l}99.5 \% \text { reduction } \\
60 \% \text { reduction } \\
99.5 \% \text { reduction } \\
96 \% \text { reduction } \\
\end{array}$ & {$[41]$} \\
\hline Arable soil, UK & $\begin{array}{l}\left(\mathrm{NH}_{4}\right)_{2} \mathrm{SO}_{4}\left(48,98,192 \mathrm{~kg} \mathrm{~N} \mathrm{ha}^{-1}\right) \\
\mathrm{KNO}_{3},\left(48,98,192 \mathrm{~kg} \mathrm{~N} \mathrm{ha}^{-1}\right)\end{array}$ & Ambient air & $\begin{array}{l}\text { reduction } \\
\text { no effect }\end{array}$ & {$[99]$} \\
\hline $\begin{array}{l}\text { Deciduous } \\
\text { forest soil, } \\
\text { Austria }\end{array}$ & $\begin{array}{l}\mathrm{KNO}_{3}\left(0,10,100, \text { and } 500 \mathrm{mg} \mathrm{N} \mathrm{kg}{ }^{-1} \text { soil }\right) \\
\left(\mathrm{NH}_{4}\right)_{2} \mathrm{SO}_{4}\left(0,10,100 \text {, and } 500 \mathrm{mg} \mathrm{N} \mathrm{kg}^{-1} \text { soil }\right)\end{array}$ & $\begin{array}{l}\text { Ambient air }(1.8 \\
\text { ppm) }\end{array}$ & $\begin{array}{l}\text { Inhibition } \\
\text { Inhibition }\end{array}$ & {$[15]$} \\
\hline $\begin{array}{l}\text { Mixed } \\
\text { deciduous } \\
\text { forest, England } \\
\end{array}$ & $\begin{array}{l}\left(\mathrm{NH}_{4}\right)_{2} \mathrm{SO}_{4}(5 \text { and } 50 \mathrm{mM}) \\
\mathrm{NH}_{4} \mathrm{Cl}(5 \text { and } 50 \mathrm{mM})\end{array}$ & Ambient air & $\begin{array}{l}\text { No effect } \\
\mathrm{NH}_{4} \mathrm{Cl}: 82-84 \%\end{array}$ & {$[100]$} \\
\hline $\begin{array}{l}\text { Coniferous } \\
\text { forest England }\end{array}$ & $\begin{array}{l}\left(\mathrm{NH}_{4}\right)_{2} \mathrm{SO}_{4}(15,30,60 \text { or } 120 \mathrm{mM}) \\
\mathrm{KNO}_{3}(15,30,60 \text { or } 120 \mathrm{mM})\end{array}$ & $\begin{array}{l}10 \text { and } 1,000 \mathrm{ppm} \\
10 \text { and } 1,000 \mathrm{ppm}\end{array}$ & $\begin{array}{l}\text { No effect } \\
70 \% \text { reduction } \\
30 \% \text { reduction } \\
70 \% \text { reduction }\end{array}$ & {$[46]$} \\
\hline
\end{tabular}




\begin{tabular}{|c|c|c|c|c|}
\hline $\begin{array}{l}\text { Deciduous } \\
\text { forest, UK }\end{array}$ & $\begin{array}{l}\mathrm{NaNO}_{3} \text { (varying con.) } \\
\mathrm{NaNO}_{2} \text { (varying con.) } \\
\mathrm{NH}_{4} \mathrm{Cl} \text { (varying con.) }\end{array}$ & $\begin{array}{l}\text { Ambient air or } \\
50,000 \mathrm{ppm}\end{array}$ & $\begin{array}{l}\text { Higher reduction } \\
\text { by the } \mathrm{NO}_{3}\end{array}$ & {$[93]$} \\
\hline $\begin{array}{l}\text { Japan } \\
\text { coniferous } \\
\text { forest } \\
\end{array}$ & $\begin{array}{l}\mathrm{KNO}_{3}\left(200 \mathrm{mg} \mathrm{N} \mathrm{kg}{ }^{-1} \text { soil }\right) \\
\text { Urea }\left(200 \mathrm{mg} \mathrm{N} \mathrm{kg}^{-1} \text { soil }\right)\end{array}$ & 2.4 and $12.6 \mathrm{ppm}$ & $\begin{array}{l}36.6 \% \text { reduction } \\
75 \% \text { reduction }\end{array}$ & {$[47]$} \\
\hline $\begin{array}{l}\text { Deciduous } \\
\text { forest soil, USA } \\
\end{array}$ & $\mathrm{NH}_{4} \mathrm{NO}_{3}\left(100 \mathrm{Kg} \mathrm{ha}^{-1}\right)$ & Ambient air & $40-60 \%$ reduction & {$[91]$} \\
\hline $\begin{array}{l}\text { Rice field soil, } \\
\text { Italy }\end{array}$ & $\begin{array}{l}\mathrm{NH}_{4} \mathrm{Cl}\left(60 \mathrm{~kg} \mathrm{~N} \mathrm{ha}{ }^{-1}\right) \\
\mathrm{NH}_{4} \mathrm{Cl}\left(60 \mathrm{~kg} \mathrm{~N} \mathrm{ha}{ }^{-1}\right) \\
\mathrm{KNO}_{3}\left(60 \mathrm{~kg} \mathrm{~N} \mathrm{ha}{ }^{-1}\right) \\
\mathrm{KNO}_{3}\left(60 \mathrm{~kg} \mathrm{~N} \mathrm{ha}{ }^{-1}\right) \\
\end{array}$ & $\begin{array}{l}1000 \mathrm{ppm} \\
10000 \mathrm{ppm} \\
1000 \mathrm{ppm} \\
10000 \mathrm{ppm} \\
\end{array}$ & $\begin{array}{l}250 \% \text { increased } \\
4 \% \text { decreased } \\
300 \% \text { increased } \\
8 \% \text { decreased } \\
\end{array}$ & {$[80]$} \\
\hline $\begin{array}{l}\text { Deciduous } \\
\text { temperate } \\
\text { forest soil, Italy }\end{array}$ & $\begin{array}{l}\mathrm{NH}_{4} \mathrm{Cl}\left(60 \mathrm{~kg} \mathrm{~N} \mathrm{ha}{ }^{-1}\right) \\
\mathrm{NH}_{4} \mathrm{Cl}\left(60 \mathrm{~kg} \mathrm{~N} \mathrm{ha}{ }^{-1}\right) \\
\mathrm{KNO}_{3}\left(60 \mathrm{~kg} \mathrm{~N} \mathrm{ha}{ }^{-1}\right) \\
\mathrm{KNO}_{3}\left(60 \mathrm{~kg} \mathrm{~N} \mathrm{ha}^{-1}\right)\end{array}$ & $\begin{array}{l}1000 \mathrm{ppm} \\
10000 \mathrm{ppm} \\
1000 \mathrm{ppm} \\
10000 \mathrm{ppm}\end{array}$ & $\begin{array}{l}4 \% \text { reduced } \\
14 \% \text { increased } \\
18 \% \text { reduced } \\
100 \% \text { increased } \\
\end{array}$ & {$[80]$} \\
\hline
\end{tabular}

\section{References}

1. WMO/UNEP, 1990. Scientific assessment of climate change, Geneva: IPCC.

2. J. Le Mer and P. Roger, "Production, oxidation, emission and consumption of methane by soils: a review", European Journal of Soil Biology, vol. 37, pp. 25-50, 2001.

3. I. Jang, S. Lee, J.H. Hong and H. Kang, "Methane oxidation rates in forest soils and their controlling variables: a review and a case study in Korea", Ecological Research, vol. 21, pp. 849-854, 2006.

4. IPCC, "Emissions scenarios, Special report of the Intergovernmental Panel on Climate Change, Cambridge University Press, UK", http:// www.ipcc.ch/pub/pub.htm.

5. J.P. Bowman, "The methanotrophs: the families Methylococcaceae and Methylocystaceae. In: The Prokaryotes (ed Dworkin M), Springer, New York, 2000,pp 266-289.

6. R.S. Hanson and T.E. Hanson, "Methanotrophic bacteria", Microbiological. Review, vol.60, pp. 439-471,1996.

7. P.A. Steudler, R.D. Bowden, J.M. Mellilo and J.D. Aber, "Influence of nitrogen fertilization on methane uptake in temperate forest soils". Nature, vol.341, pp. 314-316, 1989.

8. H. Jiang, Y. Chen, P. Jiang, C. Zhang, T.J. Smith, J.C. Murrell, and X.H. Xing, "Methanotrophs: multifunctional bacteria with promising applications in environmental bioengineering", Biochemical Engineering Journal, vol. 49, pp. 277-288, 2010.

9. EFMA (European fertilizer manufacture association), Available at: http://www.efma.org

10.M. Bender and R.Conrad, "Methane oxidation activity in various soils and freshwater sediments: occurrence, characteristics, vertical profiles and distribution on grain size fractions" Journal of Geophysical Research, vol. 99, pp. 16531-16540, 1994.

11.K.E. Dobbie and K.A. smith, "Comparison of CH4 oxidation rates in woodland, arable and set aside soils",Soil Biology \& Biochemistry, vol. 28, pp. 1357-1365, 1996.

12.L. Zhang, C. Song, X. Zheng, D. Wang and Y. Wang, "Effects of nitrogen on the ecosystem respiration, CH4 and $\mathrm{N} 2 \mathrm{O}$ emissions to the atmosphere from the freshwater marshes in northeast China". Environmental Geology, vol. 52, pp. 529-539, 2007.

13.H.Flessa, R. Ruser, R. Schilling, N. Loftfield, J.C. Munch, E.A. Kaiser and F. Beese, "N2O and CH4 fluxes in potato fields: automated measurement, management effects and temporal variation", Geoderma, vol. 105, pp.307$325,2002$.

14.S. Castaldi and A. Fierro, "Soil-atmosphere methane exchange in undisturbed and burned mediterranean shrubland of southern Italy",Ecosystem, vol. 8, pp. 182-190, 2005.

15.E. Rigler and S. Zechmeister-Boltenstern, "Oxidation of ethylene and methane in forest soils-effect of CO2 and mineral nitrogen", Geoderma, vol. 90, pp. 147-159, 1999. 
16.K.R. Tate, D.J. Ross, S. Saggar, C.B. Hedley, J. Dando, B.K. Singh and S.M. Lambie, "Methane uptake in soils from Pinus radiata plantations, a reverting shrubland and adjacent pastures: Effects of land-use change, and soil texture, water and mineral nitrogen", Soil Biology \& Biochemistry, vol. 39, pp. 1437-1449, 2007.

17.I. Kravchenko, P. Boeckx, V. Galchenko and O. Cleemput, "Short and medium-term effects of $\mathrm{NH}_{4}^{+}$on $\mathrm{CH}_{4}$ and $\mathrm{N} 2 \mathrm{O}$ fluxes in arable soils with a different texture". Soil Biology \& Biochemistry, vol. 34, pp. 669-678, 2002.

18.B.W. Hutsch, C.P. Webster and D.S. Powlson, "Methane oxidation in soil as affected by land use, soil pH and N fertilization", Soil Biology \& Biochemistry, vol. 26, pp.1613-1622. 1994

19.A. Mosier, D. Schimel, D. Valentine, K, Bronson and W. Parton, "Methane and nitrous oxide fluxes in native, fertilized and cultivated grasslands", Nature, vol. 350, pp. 330-332. 1991.

20.S.P. Nesbit and G.A. Breitenbeck, "A laboratory study of factors influencing methane uptake by soil", Agriculture, Ecosystems \& Environment, vol. 41, pp. 39-54, 1992.

21.T.W.Willison,K.W.T. Goulding and D.S.Powlson, "Effect of land-use change and methane mixing ratio on methane uptake from United Kingdom soil", Global Change Biology,vol.1, pp. 209-212, 1995.

22.W. Ding, Z. Cai and H. Tsuruta, "Cultivation, nitrogen fertilization, and set-aside effects on methane uptake in a drained marsh soil in Northeast China", Global Change Biology, vol. 10, pp. 1801-1809, 2004.

23.G. Börjesson, and H-O. Nohrstedt, "Short- and long-term effects of nitrogen fertilization on methane oxidation in three Swedish forest soils", Biology \& Fertility of Soils, vol.27, pp.113-118, 1998.

24.G. Börjesson, and H.O. Nohrstedt, "Fast recovery of atmospheric methane consumption in a Swedish forest soil after single-shot N-fertilization", Forest Ecology and Management,vol. 134, pp. 83-88, 2000.

25.R. Steinkamp, K. Butterbach-Bahl and H. Papen, "Methane oxidation by soils of an N limited and N fertilized spruce forest in the Black Forest, Germany", Soil Biology \& Biochemistry, vol. 33, pp.145-153, 2001.

26.A. Mori, M. Hojito, H. Kondo, H. Matsunami and D. Scholefield, "Effects of plant species on CH4 and N2O fluxes from a volcanic grassland soil in Nasu, Japan", Soil Science and Plant Nutrition, vol. 51, pp. 19-27, 2008.

27.P.M. Crill, P.J. Martikainen, H. Nyka"nen and J. Silvola, "Temperature and N fertilization effects on methane oxidation in a drained peatland soil", Soil Biology \& Biochemistry, vol. 26,pp. 1331-1339, 1994.

28.Hütsch, "Methane oxidation in arable soil as inhibited by ammonium, nitrite, and organic manure with respect to soil pH. Biology and Fertility of soil, vol.28, pp. 27-35, 1998.

29.S. Schnell and G.M. King, "Mechanistic analysis of ammonium inhibition of atmospheric methane consumption in forest soils", Applied and Environmental Microbiology, vol. 60, pp. 3514-3521, 1994.

30.A. Saari, P.J. Martikainen, A. Ferm, J. Ruuskanen, W. de Boer, S.R. Troelstra and H.J. Laanbroek, "Methane oxidation in soil profiles of Dutch and Finnish coniferous forests with different soil texture and atmospheric nitrogen deposition", Soil Biology \& Biochemistry, vol. 29, pp. 1625-1632. 1997.

31.R. Conrad and R. Rothfus, "Methane oxidation in the soil surface layer of a flooded rice field and the effect of ammonium", Biology \& Fertility of Soils, vol. 12, pp. 28-32, 1991.

32.U. Bosse, P. Frenzel, and R, Conrad, "Inhibition of methane oxidation by ammonium in the surface layer of a littoral sediment", FEMS Microbiology Ecology, vol. 13, pp. 124-134, 1993.

33.Nat. Van der, FJWA, J.F.C. De Brouwer, J.J. Middelburg and H.J. Laanbroek, "Spatial distribution and inhibition by ammonium of methane oxidation in intertidal freshwater marshes", Applied and Environmental Microbiology, vol.63, pp. 4734-4740, 1997.

34.P.L.E. Bodelier, P. Roslev, T. Henckel, and P. Frenzel, "Stimulation by ammonium-based fertilizers of methane oxidation in soil around rice roots" Nature, pp. 403, vol. 421-424, 2000.

35.Z. Cai and X. Yan, "Kinetic model for methane oxidation by paddy soil as affected by temperature, moisture and N addition", Soil Biology \& Biochemistry, vol. 31, pp. 715-725,1999.

36.P. Dunfield and R. Knowles, "Kinetics of inhibition of methane oxidation by nitrate, nitrite, and ammonium in a humisol", Applied and Environmental Microbiology, vol. 61, pp. 3129-3135, 1995.

37.S.C. Whalen and W.S. Reeburgh, "Effect of nitrogen fertilization on atmospheric methane oxidation in boreal forest soils", Chemosphere, vol. 2, pp. 151-155, 2000.

38.N. Tanthachoon, C. Chiemchaisri, W. Chiemchaisri, S. Tudsri and S. Kumar, "Methane oxidation in compostbased landfill cover with vegetation during wet and dry conditions in the tropics", Journal of the Air \& Waste Management Association, vol. 58, pp. 603-612, 2008.

39.W. Chen-rui, S.Yi, Y. Xiao-ming and Y. Jie W, Jin, "Advances of study on atmospheric methane oxidation (consumption) in forest soil", Journal of Forest Research, vol.14, pp.230-238, 2003. 
40.W. Borken, F. Beese, R. Brumme, and N. Lamersdorf, "Long-term reduction in nitrogen and proton inputs did not affect atmospheric methane uptake and nitrous oxide emission from a German spruce forest soil", Soil Biology \& Biochemistry, vol.34, pp.1815-1819, 2002.

41.G.M. King and S. Schnell, "Effects of ammonium and non-ammonium salt additions on methane oxidation by Methylosinus trichosporium OB3b and Maine forest soils", Applied and Environmental Microbiology, vol. 64, pp. 253-257, 1998.

42.D.B. Nedwell, "Methane production and oxidation in soils and sediments", Microbiology of atmospheric trace gases: sources, sinks and global change processes (eds Murrell JC, Kelly DP), pp 33-49. Springer-Verlag, Berlin, 1996.

43.D. Kightley, D.B. Nedwell and M. Cooper, "Capacity for methane oxidation in landfill cover soils measured in laboratory-scale soil microcosms", Applied and Environmental Microbiology, vol. 61, pp. 592-601, 1995.

44.H. Dalton, "Ammonia oxidation by the methane oxidizing bacterium Methylococcus capsulatus strain Bath", Archives of Microbiology, vol. 114, pp. 273-279, 1997.

45.C. Bedard and R. Knowles, "Physiology, biochemistry and specific inhibitors of CH4, NH4 and CO oxidation by methanotrophs and nitrifiers", Microbiological Reviews, Vol. 53, pp. 68-84, 1989.

46.Z.P. Wang and P. Ineson "Methane oxidation in a temperate coniferous forest soil: effects of inorganic N", Soil Biology \& Biochemistry, vol. 35, pp. 427-433, 2003.

47.X. Xu and K. Inubushi, "Effects of N sources and methane concentrations on methane uptake potential of a typical coniferous forest and its adjacent orchard soil", Biology \& Fertility of Soils, vol.40, pp.215-221, 2004.

48.J.G. O'Neill and J.F. Wilkinson, "Oxidation of ammonia by methane-oxidizing bacteria and the effects of ammonia on methane oxidation", Journal of General Microbiology, vol. 100, pp. 407-412, 1977.

49.M.G. Klotz and J.M. Norton, "Multiple copies of ammonia monooxygenase (amo) operons have evolved under biased AT/GC mutational pressure in ammonia-oxidising autotrophic bacteria", FEMS Microbiology Letters, vol.168, pp. 303-311, 1998.

50.A.J. Holmes, A.M. Costello, M.E. Lidstrom and J.C. Murrell, "Evidence that particulate methane monooxygenase and ammonia monooxygenase may be evolutionarily related", FEMS Microbiology Letters, vol. 132, pp. 203-208, 1995.

51.J.D. Semrau, A. Chistoserdova, J. Lebron, A. Costello, J. Davagnino, E. Kenna, A.H. Holmes, R. Finch, J.C. Murrell and M.E. Lidstrom, "Particulate methane monooxygenase genes in methanotrophs", Journal of Bacteriology, vol.177, pp. 3071-3079, 1995.

52.B. Gilbert, I.R. McDonald, R.Finch, G.P. Stafford, A.K. Nielsen and J.C. Murrell, "Molecular analysis of the pmo (particulate methane monooxygenase) operons from two type II methanotrophs", Applied Environmental Microbiology, vol. 66, pp.966-975, 2000.

53.T. Yoshinari "Nitrite and nitrous oxide production by Methylosinus trichosporium. Canadian Journal of Microbiology, vol.31, pp.139-144,1984.

54.R.D. jones, and R.Y. Morita, "Survival of a marine ammonium oxidizer under energy-source deprivation", Marine ecology progress series vol. 26, pp. 175-179, 1985.

55.P.L.E. Bodelier and P. Frenzel, "Contribution of methanotrophic and nitrifying bacteria to $\mathrm{CH} 4$ and $\mathrm{NH}_{4}^{+}$ oxidation in the rhizosphere of rice plants as determined by new methods of discrimination", Applied and Environmental Microbiology, vol. 65, pp.1826-1833, 1999.

56.R. Roy and R. Knowles, "Differential inhibition by allylsulfide of nitrification and methane oxidation in freshwater sediment", Applied and environmental Microbiology, vol. 61, pp. 4278-4283. 1995.

57.S.R. Megraw and R. Knowles, "Effect of picolinic acid (2-pyridine carboxylic acid) on the oxidation of methane and ammonia in soil and in liquid culture". Soil Biology \& Biochemistry, vol. 22, pp. 635-641, 1990.

58.E.M. Baggs and H. Blum, "CH4 oxidation and emissions of $\mathrm{CH} 4$ and $\mathrm{N} 2 \mathrm{O}$ from Lolium perenne swards under elevated atmospheric CO2", Soil Biology \& Biochemistry, vol. 36, pp. 713-723, 2004.

59.A. Boiesen, E. Arvin, and K. Broholm, "Effect of mineral nutrients on the kinetics of methane utilization by methanotrophs", Biodegradation, vol.4, pp.163-170, 1993.

60.J. Gulledge, A.P. Doyle, and J.P., Schimel, "Different $\mathrm{NH}_{4}{ }^{+}$-inhibition patterns of soil CH4 consumption: A result of distinct CH4-oxidizer populations across sites", Soil Biology \& Biochemistry, 29, 13-21,1997.

61.A. Hermansson and P.E. Lindgren, "Quantification of ammonia oxidizing bacteria in arable soil by real-time PCR", Applied and Environmental Microbiology, vol. 67, 972-976, 2001. 
62.A.S.K. Chan and T.B. Parkin, "Methane oxidation and production activity in soils from natural and agricultural ecosystems", Journal of Environmental Quality, vol. 30, pp. 1896-1903, 2001.

63.S. Kolb, C. Knief, P. Dunfield and R.Conrad, "Abundance and activity of uncultured methanotrophic bacteria involved in consumption of atmospheric methane in two forest soils", Environmental Microbiology, vol.7, pp.1150-1162, 2005.

64.M.S. Castro, P.A. Steudler and J.M. Mellilo, "Factors controlling atmospheric methane consumption by temperate forest soils", Global Biogeochemical Cycle, vol. 9, pp. 1-10, 1995.

65.T. Henckel, U. Jäckel, S. Schnell and R. Conrad, "Molecular analyses of novel methanotrophic communities in forest soil that oxidize atmospheric methane", Applied and Environmental Microbiology, vol. 66, pp. 1801-1808, 2000 .

66.D.S. Reay, D.B. Nedwell, N. McNamara, P. Ineson, "Effect of tree species on methane and ammonium oxidation capacity in forest soils", Soil Biology \& Biochemistry vol. 37, pp. 719-730, 2005.

67.P. Roslev and N. Iversen, " Radioactive fingerprinting of microorganisms that oxidize atmospheric methane in different soils". Applied and environmental Microbiology, vol. 65, pp. 4064-4070, 1999.

68.P.J. Maxfield, E.R.C Hornibrook and R.P. Evershed, "Acute impact of agriculture on high-affinity methanotrophic bacterial populations", Environmental Microbiology, vol. 10, pp. 1917-1924, 2008.

69.J. Gulledge and J.P. Schimel, "Low-concentration kinetics of atmospheric CH4 oxidation in soil and mechanism of $\mathrm{NH}_{4}{ }^{+}$inhibition".,Applied and Environmental Microbiology, vol. 64, pp. 4291-4298, 1998.

70.S. Schnell and G.M. King, "Responses of methanotrophic activity in soils and cultures to water stress", Applied and Environmental Microbiology, vol. 62, pp. 3203-3209,1996.

71.M.A Ka"hko"nen, C. Wittmann, H. Ilvesniemi, C.J.Westman, and M.S. Salkinoja-Salonen, "Mineralization of detritus and oxidation of methane in acid boreal coniferous forest soils: seasonal and vertical distribution and effects of clear-cut", Soil Biology \& Biochemistry, vol.34, pp.1191-1200, 2002.

72.A. Saari, A. Smolander and P.F. Martikainen, "Methane consumption in a repeatedly nitrogen-fertilised and limed spruce forest soil after clear-cutting", Soil Use Management, vol. 20, pp. 65-73, 2004.

73.A.H. Magill, J.D. Aber, J.J. Hendricks, R.D. Bowden, J.M. Melillo and P. Steudler, "Biogeochemical response of forest ecosystems to simulated chronic nitrogen deposition", Ecological Applications, vol. 7, pp. 402-415, 1997.

74.P.A. Steudler, R.D. Jones, M.S. Castro, J.M. Melillo and D.L. Lewis, Microbial controls of methane oxidation in temperate forest and agricultural soils. In: Microbiology of atmospheric Trace Gases. Sources, Sinks and Global Change (eds Murrel JC, Kelly DP), NATO ASI Series, Springer, Berlin, pp 69-84, 1995.

75.A.P.S. Adamsen and G.M. King, "Methane consumption in temperate and subarctic forest soils: rates, vertical zonation, and responses to water and nitrogen", Applied and Environmental Microbiology, vol. 59, pp. 485-490, 1993.

76.M.B. Goldman, P.M. Groffman, R.V. Pouyat, M.J. McDonnell and S.T.A. Pickett, "CH4 uptake and N availability in forest soils along an urban to rural gradient",Soil Biology \& Biochemistry, vol. 27, pp. 281-286, 1995.

77.S.K. Dubey and J.S. Singh, "Spatio-temporal variation and effect of urea fertilization on methanotrophs in a tropical dryland rice field", Soil Biology \& Biochemistry, vol. 32, pp.521-525, 2000.

78.D. Seghers, S.D. Siciliano, E.M. Top and W. Verstraete, "Combined effect of fertilizer and herbicide applications on the abundance, community structure and performance of the soil methanotrophic community", Soil Biology \& Biochemistry, vol. 37, pp. 187-193, 2005.

79.A. De Visscher and O. Van Cleemput, "Induction of enhanced methane oxidation in soils: Ammonium inhibition patterns", Soil Biology \& Biochemistry, vol. 35, pp. 907-913, 2003.

80.S.R. Mohanty, P.L.E. , Bodelier, V. Floris and R. Conrad, "Differential effects of nitrogenous fertilizers on methane-consuming microbes in rice field and forest soils". Applied and Environmental Microbiology, vol. 72, pp. 1346-1354, 2006.

81.Z.M. Crossman, Z.P. Wang, P. Ineson and R.P. Evershed, "Investigation of the effect of ammonium sulfate on populations of ambient methane oxidizing bacteria by 13C-labelling and GC/C/IRMS analysis of phospholipid fatty acids", Soil Biology \& Biochemistry, vol. 8, pp. 983- 990, 2006.

82.D.W. Graham, J.A. Chaudhary, R.S. Hanson and R.G. Arnold, "Factors affecting competition between type I and type II methanotrophs in continuous-flow reactors", Microbial Ecology, vol. 25, pp. 1-17, 1993. 
83.S. Saitoh, K. Iwasaki and O. Yagi, "Development of a new most probable-number method for enumerating methanotrophs, using 48-well microtiter plates microbes and environments", Microbes and Environment, vol.17, pp. 191-196, 2002.

84.E. Lau, A. Ahmad, P.A. Steudler and C.M. Cavanaugh, "Molecular characterization of methanotrophic communities in forest soils that consume atmospheric methane", FEMS Microbiology Ecology, vol. 60, pp. 490$500,2007$.

85.M. Noll, P. Frenzel and R. Conrad, " Selective stimulation of type I methanotrophs in a rice paddy soil by urea fertilization revealed by RNA-based stable isotope probing", FEMS Microbiology Ecology, vol. 165, pp. 125-132, 2008.

86.B.K. Sitaula, L.R. Bakken and G. Abrahamsen,"CH4 uptake by temperate forest soil: effect of N input and soil acidification", Soil Biology \& Biochemistry, vol. 27, pp. 871-880, 1995.

87.G.M. King and S. Schnell, "Effect of increasing atmospheric methane concentration on ammonium inhibition of soil methane consumption", Nature, vol.370, pp. 282-284, 1994a.

88.D.R. Jollie and J.D. Lipscomb, "Formate dehydrogenase from Methylosinus trichosporium OB3b: purification and spectroscopic characterization of the cofactors", J. Biol. Chem., vol. 266, pp. 21853-21863, 1991.

89.G.M. King and S. Schnell, "Ammonium and nitrite inhibition of methane oxidation by Methylobacter albus BG8 and Methylosinus trichosporium OB3b at low methane concentrations", Applied and Environmental Microbiology, vol. 60, pp.3508-3513, 1994b.

90.Hütsch, "Methane oxidation in arable soil as inhibited by ammonium, nitrite, and organic manure with respect to soil pH", Biology and Fertility of soil, vol. 28, pp. 27-35, 1998.

91.P. Suwanwaree and G.P. Robertson, "Methane oxidation in forest, successional, and no-till agricultural ecosystems: effects of nitrogen and soil disturbance", Soil Science, vol. 69, pp. 1722-1729, 2005.

92.J.A. Mac donald, U. Skiba, L.J. Sheppard, B. Ball, J.D. Roberts, K.A. Smith and D. Fowler, "The effect of nitrogen deposition and seasonal variability on methane oxidation and nitrous oxide emission rates in an upland spruce plantation and moorland", Atmospheric Environment, vol. 31, pp. 3693-3706, 1997.

93.D.S. Reay and D.B. Nedwell, "Methane oxidation in temperate soils: effects of inorganic N. Soil Biology \& Biochemistry", vol. 36, pp. 2059-2065, 2004.

94.D.R. Nayak, Y.J. Babu, A. Datta and T.K. Adhya, "Methane oxidation in an intensively cropped tropical rice field soil under long-term application of organic and mineral fertilizers", Journal of Environmental Quality, vol. 36, pp. 1577-1584, 2007.

95.P.R. Afolabi, F. Mohammed, K. Amaratunga, O. Majekodunmi, S.L. Dales, R. Gill, D. Thompson, J.B. Cooper, S.P. Wood, P.M. Goodwin and C. Anthony, "Site-directed mutagenesis and X-ray crystallography of the PQQcontaining quinoprotein methanol dehydrogenase and its electron acceptor cytochrome c." Biochemistry, vol. 40, pp. 9799-9809, 2001.

96.P. Hothi, J. Basran, M.J. Sutcliffe and N.S. Scrutton, "Effects of multiple ligand binding on kinetic isotope effects in PQQ-dependent methanol dehydrogenase", Biochemistry, vol. 42, pp. 3966-3978, 2003.

97.R. Whittenbury, K.C. Philips and J.F. Wilkinson, "Enrichment, isolation and some properties of methaneutilizing bacteria", Journal of General Microbiology, vol.61, pp. 205-218, 1970.

98.S.C. Whalen, W.S. Reeburgh and K.S. Kiser, "Methane consumption and emission by taiga", Global Biogeochemical Cycles, vol.5, pp. 261-273. 1991.

99.P. Tlustos, T.W. Willison, J.C. Baker, D.V. Murphy, D. Pavlikova, Goulding K.W.T. and, D.S. Powlson, "Short-term effects of nitrogen on methane oxidation in soils", Biology \& Fertility of Soil, vol. 28,pp. 64-70, 1998.

100.M.A. Bradford, P.A. Wookey, P. Ineson and H.M. Lappin-Scott, "Controlling factors and effects of chronic nitrogen and sulphur deposition on methane oxidation in a temperate forest soil", Soil Biology \& Biochemistry, vol. 33, pp.93-102, 2000. 